\title{
Utilization of Turi Leaf Flour in Feed (Sesbania grandiflora Pers.) on Growth of Black Nile Tilapia (Orechromis niloticus)
}

\author{
Ummul Firmani $^{1}$, Yudi Cahyoko ${ }^{2}$, and Mustikoweni ${ }^{3}$ \\ ${ }^{1}$ Faculty of Agriculture, University of Muhammadiyah Gresik, Street of Sumatra Number 101, GKB, Gresik, East Java, \\ Indonesia61121 ummul.buper@yahoo.com \\ ${ }^{2,3}$ Faculty of Fisheries and Marine Science, University of Airlangga, Street of North Mulyorejo, Surabaya, East Java, Indonesia
}

\begin{abstract}
Ummul Firmani, Yudi Cahyoko, and Mustikoweni. 2015. Utilization of Turi Leaf Flour in Feed (Sesbania grandiflora Pers.) on Growth of Black Nile Tilapia (Orechromis niloticus). Aquacultura Indonesiana, 16 (2): 69-72. Critical factor for successful fish farming is feed. Feed should always be available and in accordance with the needs of farmed fish both in quality and quantity. Black nile tilapia is reared intensively, requires diet crumb size with protein content is not less than 30\%. Diet made by the composition and nutritional value in accordance with the age of the fish. The purpose of this study was to find the optimum percentage of Turi leaf meal in artificial feed on the growth of black nile tilapia's weight about $6 \mathrm{~g} /$ fish. The treatment in this study was the addition of Turi leaf flour in artificial feed at $0 \%, 3 \%, 6 \%, 9 \%$ and $12 \%$. Fish stocking density is maintained with 1 fish/L water for 40 days in a plastic tub volume of 15 liters and given the aerator. Measurement the amount of feed consumed was calculated to determine the feed efficiency. Data were analyzed using ANOVA and then the differences between treatments were tested using Duncan's Multiple Range Test. The results showed the highest of daily specific growth rate and feed efficiency obtained in the treatment of feed containing Turi leaf flour of 0-9\% were respectively 1.66 to $1.57 \%$ and from 45.57 to $39.82 \%$.
\end{abstract}

Keywords : Black nile tilapia; Daily specific growth rate; Feed efficiency; Turi leaf flour

\section{Introduction}

Black tilapia (Oreochromis niloticus) is one species of freshwater fish to be cultivated intensively. This is due to black tilapia has several advantages compared to freshwater fish consumption among fast growth, tolerant to physical-chemical water changes, easily cultivated, breeding fast, high survival, large body size, white meat and the savory taste of meat (Rukmana, 1997). One factor that is critical for successful fish farming is feed. Feed should always be available and in accordance with the needs of farmed fish both in quality and quantity. According to Suyanto (1994), tilapia fish is reared intensively, requires that the form of feed diet size crumb with protein content of not less than $30 \%$ to meet the nutritional needs of tilapia cultured, then made his own in the form of feed diets. Diet made to the composition and nutritional value in accordance with the age of the fish. Diet size adjusted to the fish's mouth openings. This is expected to support optimal growth of black tilapia. Utilization of feed raw materials that have a high nutrient content, easily obtained, easily processed, easily digested fish, the price is relatively cheap or even human waste, not toxic, not for human consumption, should be done as much as possible (Hariati, 1989).

Turi (Sesbania grandiflora Pers.) is a plant that grows in many rurals. This plant has several benefits, especially the leaves have great requirements for use as a raw material in the manufacture of fish feed. According to Hartadi et al. (1990), nutrient content of Turi leaf has protein $(29.6 \%)$, fat $(5 \%)$, carbohydrates $(42.5 \%)$, crude fiber $(15.6 \%)$, vitamins and minerals. Based on the results of research conducted by Masithah and Luqman (1999), the use of Turi leaves as feed material for red tilapia fish with a weight of 1.9 $\mathrm{g} /$ fish from a maximum of $4.6 \%$ total feed ration. Jauncey and Ross (1982) states that fish with different body weight also have differences of feed proteins needed. Black nile tilapia which has weight $0.5-10 \mathrm{~g} /$ fish requires feed with a protein content about $40 \%$, while black nile tilapia which has weight $10-30 \mathrm{~g} / \mathrm{fish}$ requires feed with a protein content about $30-35 \%$. This is due to the increasing age, the development of digestive tract and increasingly capability of digesting feed, so the need for protein, fat and energy is also different. This will affect to the type and amount of feed that is consumed by fish (Lagler et al., 1977).

Therefore, this study examined the effect of adding Turi leaf flour in artificial feed on the growth of black nile tilapia's weight \pm 6 g/fish and percentage use in feed rations optimized for the growth of black nile tilapia.

\section{Materials and Methods}

\section{Material}

The materials used in this study include black tilapia (Oreochromis niloticus) are 
weighted $\pm 6 \mathrm{~g} /$ fish amount 100 fish, cylindrical black plastic tubs with volume of $15 \mathrm{~L}$ and total of 20 pieces, aerators, and the diet containing a mixture of Turi leaves flour, soybean meal, fish meal, corn flour, tapioca flour, fish oil, vitamins and minerals.

\section{Methods}

The method used in this study is the experimental method. The study design is completely randomized design (CRD). The treatment is percentage of Turi leaf in feed and repeated 4 times as listed in Table 1.

Table 1. Percentage of turi leaf flour in feed formulation

\begin{tabular}{cc}
\hline Treatment & Percentage of turi leaf flour \\
\hline T0 & $0 \%$ \\
T1 & $3 \%$ \\
T2 & $6 \%$ \\
T3 & $9 \%$ \\
T4 & $12 \%$ \\
\hline
\end{tabular}

Fish was cultured in fresh water (previously aerated for 1 day) that placed in plastic tubs and given aerator. Each tub filled 5 fish with stocking density 1 fish $/ 3$ liters of water. The water culture temperature is controlled between $25-30^{\circ} \mathrm{C}$ and $\mathrm{pH}$ between 6-8. Water culture replaced every day as much as $50 \%$ of the total volume of water. Fish feces is remove every day to maintain good water quality for culture. Feed used for this treatment is dry diet-shaped artificial feed that size is adjusted to the size of the fish's mouth openings. The process of drying feed material is done by using a preheated oven at $70^{\circ} \mathrm{C}$ for 24 hours. Feed is given to fish every day as much as $3 \%$ of the fish biomass with the frequency of feeding is 3 times a day i.e at 07:00, 12:00 and 17:00 pm. Adjustment of the amount of feed is done every 10 days after weighing the fish. Before weighing, the fish were fasted the day before.

\section{Data Analysis}

Data are analized with the analysis of variance, and then analized the difference between treatments used Duncan's Multiple Range Test (Duncan's Multiple Range Test) (Kusriningrum, 1989). The growth rate used to calculate the formula proposed by Huismann (1976) as follows:

$$
\overline{W t}=\overline{W o}(1+0,01 \alpha)^{t}
$$

Description :

$W t=$ The average weight of individual fish at time $\mathrm{t}(\mathrm{g})$ $W o=$ The average weight of individual fish at time $\mathrm{t}=0(\mathrm{~g})$ $\alpha=$ Individual daily growth rate (\%)

$\mathrm{t}=$ time (days)

To calculate feed efficiency, use the formula proposed by the Northeastern Regional Aquaculture Center (1977) is as follows:

$$
\mathrm{e}=\frac{\left(\mathrm{W}_{\mathrm{t}}+\mathrm{D}\right)-\mathrm{W}_{0}}{\mathrm{~F}} \times 100 \%
$$

Description :

$\mathrm{e}=$ feed efficiency $(\%)$

$\mathrm{Wt}=$ weight of the fish biomass at the end of the $\operatorname{study}(\mathrm{g})$

W0 $=$ weight of the fish biomass at baseline $(\mathrm{g})$

$\mathrm{D}=$ the total weight of fish that died during the study $(\mathrm{g})$

$\mathrm{F}=$ the amount of feed given $(\mathrm{g})$

\section{Results}

The graph in Figure 1 below shows that the highest weight of fish achieved in feed

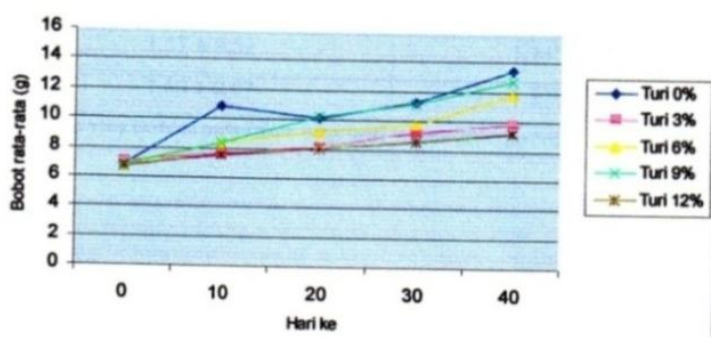

containing Turi leaves at $0 \%$, and successively followed by feed containing Turi leaves at $9 \%$, $6 \%, 3 \%$ and $12 \%$.

Figure 1. Chart of daily growth rate of black nile tilapia $(O$. niloticus)

Statistical test results in Table 2 show that the percentage difference of Turi leaves in feed at $0 \%, 3 \%, 6 \%, 9 \%$ and $12 \%$ resulted in the different growth rate of black tilapia $(P<0.05)$. The highest growth rate obtained on the T0 $(1.66 \%)$ was same as T3 $(1.57 \%)$ and is not different from T2 $(1.41 \%)(P>0.05)$, while the lowest growth rate obtained on the T4 treatment $(0.77 \%)$ is not different from $\mathrm{T} 1(0.80 \%)(P>$ $0.05)$.

Statistical test results in Table 3 show that the percentage difference of Turi leaves in feed at $0 \%, 3 \%, 6 \%, 9 \%$ and $12 \%$ produce different feed efficiency $(P<0.05)$. The highest feed efficiency obtained at T0 treatment $(45.57 \%)$ which is equal to $\mathrm{T} 3(39.82 \%)$ and $\mathrm{T} 2$ $(38.59 \%)$ or $(P>0.05)$, while the lowest feed efficiency obtained in treatment T4 $(21.52 \%)$ and T1 $(26.68 \%)$ or $(P<0.05)$. 
Table 2. Average of daily growth rate (\%) black nile tilapia (O. niloticus) in every treatment for 40 days.

\begin{tabular}{ccc}
\hline Treatments & Daily growth rate \pm SD & Transformation $\sqrt{ } \mathrm{Y} \pm \mathrm{SD}$ \\
\hline T4 (12\%) & $0.77 \pm 0.46$ & $0.85^{\mathrm{c}} \pm 0.26$ \\
T1 (3\%) & $0.83 \pm 0.36$ & $0.89^{\mathrm{bc}} \pm 0.21$ \\
T2 (6\%) & $1.41 \pm 0.27$ & $1.18^{\mathrm{ab}} \pm 0.11$ \\
T3 (9\%) & $1.57 \pm 0.52$ & $1.24^{\mathrm{a}} \pm 0.20$ \\
T0 (0\%) & $1.66 \pm 0.57$ & $1.27^{\mathrm{a}} \pm 0.22$ \\
\hline
\end{tabular}

Direction: Different superscript shows significant different result $(P<0.05)$.

Table 3. Average of feed efficiency (\%) black nile tilapia (O. niloticus) in every treatment for 40 days.

\begin{tabular}{ccc}
\hline Treatment & Feed efficiency \pm SD & Transformation $\sqrt{\mathrm{Y}} \pm \mathrm{SD}$ \\
\hline $\mathrm{T} 4(12 \%)$ & $21.52 \pm 6.99$ & $4.59^{\mathrm{c}} \pm 0.62$ \\
$\mathrm{~T} 1(3 \%)$ & $26.68 \pm 6.25$ & $5.14^{\mathrm{b}} \pm 0.76$ \\
$\mathrm{~T} 2(6 \%)$ & $38.59 \pm 11.04$ & $6.16^{\mathrm{a}} \pm 0.93$ \\
$\mathrm{~T} 3(9 \%)$ & $39.82 \pm 3.64$ & $6.31^{\mathrm{a}} \pm 0.29$ \\
$\mathrm{~T} 0(0 \%)$ & $45.57 \pm 2.32$ & $6.75^{\mathrm{a}} \pm 0.8$ \\
\hline
\end{tabular}

Direction: Different superscript shows significant different result $(P<0.05)$.

\section{Discussion}

Growth is a process of metabolism that occurs in the body of living creatures that begins with taking food and ending with the preparation of body tissues (Heinsbroek, 1988). Further, growth is defined as weight gain and volume within a certain time. The daily value growth rate shows the change in the average weight of individual fish by time. Weight gain or body length at a given time is called the absolute growth (Effendie, 1997). The average growth rate of the fish in this study increased as increasing maintenance time. This is thought to be caused Turi leaves contain protein quite high at $30 \%$. In addition, the feed used also contain soybean meal and fish meal containing protein is high enough. Fish meal made from whole fish are good quality protein content by $60-80 \%$, is rich in energy and minerals and digestibility by $80-95 \%$ (Lovell, 1989). Cruz and Laudensia (1978) in Muir and Robert (1982) said that the combination of fish meal and soy flour has a very important role as the building blocks of protein fish feed. The second role of the material in fish feed can not be replaced by feed ingredients such as rice, copra meal, and sorghum.

The growth rate is closely related to body weight gain derived from the use of proteins, fats and carbohydrates of feed consumed by fish (Bardach et al., 1972). The results showed that the highest growth rate obtained in the treatment of feed containing Turi leaves flour at $0 \%$. Furthermore, the rate of growth in a row tends to decrease in feed containing Turi leaves flour at $9 \%, 6 \%, 3 \%$ and $12 \%$. A decrease in the growth rate is apparently due in Turi leaf meal still contains compounds HCN (cyanide) and some alkaloids that are toxic for fish. Turi leaves dried at $70^{\circ} \mathrm{C}$ for 24 hours allegedly still contain these compounds. Hendricks et al. (1981) in Halver (1989) inform the result study for rainbow trout (Salmo gairdneri) that given feed containing complex pyrrolizidine alkaloids, indicating that the fish undergo necrosis of the cells, nodular regeneration, liver hardens, damages to the endothelium and the core and thickening of the glomerular kidney. Radeleff (1970) stated that HCN can damage tissue by inhibiting oxidative enzymes function as cytochrome oxidase, so that it will inhibit the function of the respiratory enzyme. This is because of the onset of damage and disruption of the function of the multiple organs that may indirectly interfere with the function of the digestive organs. Thus, it impaires nutrient absorption and causes in growth decreased. The highest growth rate was achieved in the treatment $\mathrm{T} 0(0 \%)$ that is same as the treatment T2 (6\%) and T3 (9\%), followed by T1 $(3 \%)$ and $\mathrm{T} 4(12 \%)$. A decrease in the growth rate at $\mathrm{T} 1(3 \%)$ suspected of sex differences in the fish studied. Allegedly, the treatment Tl (3\%) is widely available female tilapia than males. Female tilapia growth rate is lower than male. This is in accordance with the opinion of Lovell (1989), that female fish has a lower growth rate than the male. In addition, the fish used in this study probably derived from different parent who has a different genetic potential, so it has a different growth rate. This is supported by the opinion of Einsminger et al. (1990) that the nutritional needs for growth is influenced by age, parent, sex, growth, and health. 
Feed efficiency is defined as weight gain compared to the amount of fish feed consumtion. As the increasing content of Turi leaf flour in feed, the feed efficiency is decreases. The decreasing of feed efficiency, which is caused by the inability of black tilapia utilizes the overall feed containing Turi leaf flour, as a source of energy and the material that formes the body of the fish.

Based on this research, it can be concluded that the addition of Turi leaf flour in feed rations optimal artificial can promote the growth of black tilapia weighing $\pm 6 \mathrm{~g} / \mathrm{fish}$ is equal to 6-9\%. Suggestions for future research need to be done research on alkaloid levels in Turi leaf flour after being processed by drying and research must be done by using tilapia that comes from the same parent and the same sex.

\section{Acknowledgement}

We would like to thank Departement Fisheries and Maritim Faculty of Veternary, Airlangga University. Many thanks to other that contribute for this research.

\section{References}

Bardach, J.E., J.H. Ryther, and W.C. McLarney. 1972. Aquaculture. Willey International Science. New York. 868p.

Effendie, M.I. 1997. Biologi Perikanan. Yayasan Pustaka Nusatama. Yogyakarta. 163 hal.

Einsminger, M.E., J.E. Oldfield, and W.W. Heinemann. 1990. Feeds and Nutrition. Second Edition. The Einsminger Publishing Company. California. 765p.

Halver, J.E. 1989. Fish Nutrition. Second Edition. Academic Press, Inc. California. 789p.

Hariati, A.M. 1989. Makanan Ikan. Universitas Brawijaya. Malang. $155 \mathrm{hlm}$.
Hartadi, H., S. Reksohadiprodjo, and A.D. Tilman. 1990. Tabel Komposisi Pakan untuk Indonesia. Gadjah Mada University Press. Yogyakarta.

Heinsbroek, L.T.N. 1988. Growth and Feeding of Fish. Departement of Fish Culture and Fisheries Agricultural University. Wageningen. 84p.

Huismann, E.A. 1976. Food conversion efficiencies maintenance and production levels for Carp, Cyprinus carpio L. and Rainbow Trout, Salmo gairdneri. Aquaculture, 9 : $259-273$.

Jauncey, K. and B. Ross. 1982. A Guide to Tilapia Feeds and Feeding. Institut of Aquaculture. University of Stirling. Scotland. 111p.

Kusriningrum, R. 1989. Dasar Perancangan Percobaan dan Rancangan Acak Lengkap. Universitas Airlangga. Surabaya. 143 hal.

Lagler, K.F., J.E. Bardach, R.R. Miller, and D.R.M. Passion. 1977. Ichthyology. John Willey and Sons. New York. 505p.

Lovell, T. 1989. Nutrition and Feeding of Fish. Van Nostrand Reinhold. New York. 260 p.

Masithah, E.D. and E.M. Luqman. 1999. Pemanfaatan Tepung Daun Turi (Sesbania grandiflora Pers.) Sebagai Sumber Protein Nabati dalam Pakan Ikan. Media Kedokteran Hewan XV. 2: $135-140$.

Muir, J.F. and R.J. Roberts. 1982. Recent Advances in Aquaculture. Westview press. Colorado. 465p.

Northeastern Regional Aquaculture Center. 1993. Introduction to Water Chemistry Freshwater Aquaculture. University of Massachusetts. North Darmouth. Massachusetts. Nomor 170.

Radeleff, R.D. 1970. Veterinary Toxicology. Second Edition. Lea and Febiger. Philadelphia. $352 p$.

Rukmana, R. 1997. Ikan Nila, Budidaya dan Prospek Agribisnis. Kanisius. Yogyakarta. 90 hal.

Suyanto, S.R. 1994. Nila. Penebar Swadaya. Jakarta. $105 \mathrm{hlm}$ 